ISSN: 2224-0616

Int. J. Agril. Res. Innov. \& Tech. 5(2): 1-6, December, 2015

Available online at http://www.ijarit.webs.com

\title{
RICE MARKET INTEGRATION IN SOUTHERN SUMATRA, INDONESIA
}

\section{Yetty Oktarina}

Received 12 May 2015, Revised 17 October 2015, Accepted 22 December 2015, Published online 31 December 2015

\begin{abstract}
This paper investigates rice market integration among five provinces in southern Sumatra using data from monthly retail rice markets during 2004-2009. The degree of integration was measured across provinces using vector error correction model. Result revealed that there is spatial market integration in southern Sumatra. Province of Bangka Belitung can make price adjustment more quickly compared to others provinces. In the long run period, rice price in Jambi province, Lampung province, and Bangka Belitung province became a reference price of rice in southern Sumatra. The study suggests policy recommendation for government to intervention this situation.
\end{abstract}

Keywords: Vector Error Correction Model, Rice Price, Market, Integration, Southern Sumatra

Department of Agriculture, University of Baturaja, Jl. Ratu Penghulu Karang Sari No.02301, Kabupaten Ogan Komering Ulu, Provinsi Sumatra Selatan, Indonesia

*Corresponding author's email: yetty_oktarina@unbara.ac.id (Yetty Oktarina)

\section{Introduction}

Rice is produced in many regions of Southern Sumatra in Indonesia. The diversity of each region has causing variation of the number of production and rice prices. As shown in Table 1, rice price in Southern Sumatra region is volatile to trigger market integration during 2010-2011. The question then is how do we understand the process of rice market integration in Southern Sumatra region? From the practical side, understanding this situation is becoming critical because the government needs to stabilize rice price. This study was designed to investigate rice market integration in Southern Sumatra by using vector error correction model (VECM). Researchers also will discuss the implications of the research findings for government's policy in the rice trade.

Theoretically, market integration consists of spatial and vertical integration. There is spatial market integration when there is trading between two or more market in different place. Price in importer area is equivalent with price in exporter area. Price change in one market is a reflection of price change of similar product in other place in one geographical area. However, market integration itself does not automatically mean perfectly competitive market (Ravallion, 1986).

Market has been integrated vertically if price change in one place is reflected by price changes at different markets vertically for the same product in one geographical area. Vertical integration is closely related to the concept of marketing margins, especially producerconsumer margins or producer-retail margins. If market is fully integrated vertically, then intervention on the consumer/retail traders will influenced producer market. Otherwise, if markets are not integrated, interventions will not achieve desired target at the level of producer prices (Trotter, 1992).

Previous research shows diverse findings on rice market integration in Indonesia. For example, Alexander and Wyeth (1994) stated that among the rice prices: no cointegration was indicated between Surabaya and Ujung Pandang and causality was found to be moving in only one direction from them toward other cities, with little flowing back in their direction. This result suggest the importance of Surabaya and Ujung Pandang as driving forces in rice formation and it can be explain the fact that each is the major sources of surplus rice at different time of the year: Surabaya in the first part of the year and Ujung Pandang in the second. It is likely that demand remains much steadier than supply over the course of a year and this may be why prices changes originate at these supply centre.

Meanwhile, Bustaman (2003) showed that in general, rice market at the provincial level in Indonesia is mutually integrated with other provinces, either in the short or long term. All provinces in Indonesia are connected into one integrated trading system so that market equilibrium will affect balancing in others market. High-quality market integration is an indicator for efficient performance of rice marketing in domestic area. 
Varela et al. (2013) indicate wide market integration and low price difference in the range of 5-12 percent for rice market. Integration across provinces is explained by the remoteness and quality of transport infrastructure of a province.
Price difference across provinces respond to variations in provincial characteristics, Reviews such as remoteness, transport infrastructure, the output of the commodity, land productivity, and income per capita.

Table 1. Rice price at province level in Southern Sumatra area during 2010-2011*

\begin{tabular}{lll}
\hline \multirow{2}{*}{ Province } & \multicolumn{2}{c}{ Price $(\mathrm{Rp} / \mathrm{Kg})$ and year } \\
\cline { 2 - 3 } & 2010 & 2011 \\
\hline Sumatra Selatan & 6.536 & 6.827 \\
Lampung & 6.625 & 7.059 \\
Jambi & 6.733 & 7.014 \\
Bengkulu & 6.752 & 7.243 \\
Bangka Belitung & 6.762 & 7.769 \\
\hline
\end{tabular}

Source: Central Bureau of Statistic (2012)

*Data was transformed by researcher

This research was designed to entering debate on rice market integration in Indonesia, especially in Southern Sumatra region. I hope my finding on this topics make our understanding more comprehensive.

\section{Materials and Methods}

This research was conducted in Southern Sumatra region that includes five provinces, namely: Sumatra province, Lampung province, Jambi province, Bengkulu province, and Bangka Belitung province. The research was conducted in March- December 2011 period. This study uses times series data from 2004 to 2009 (6 year) based on monthly retail price of rice. Data was collected from Department of Commerce, Central Bureau of Statistic, and Department of Agriculture.

We apply Vector Autoregression (VAR) model to investigate market integration. Data will be tested with a series of tests such as stationary test with Augmented Dickey-Fuller (ADF) (Thomas, 1997), optimal lag test, cointegration test with adjusted $\mathrm{R}^{2}$ statistic, F-test, t-test, likelihood ratio test, or maximum eigenvalue statistics (Pindyck and Rubinfeld, 1981), analysis of impulse response (Widarjono, 2007), and variance decomposition (Maknun, 2008).

\section{Results and Discussion}

\section{Stationarity test}

As shown in Table 2, not all data is stationary at I(0), except Bengkulu province and Bangka Belitung province. It means that data should be stationary at I(1). The results of stationary test in the first differentiation or I(1) is shown in Table 3 . The results showed that data used in this study is not stationary at $\mathrm{I}(0)$ but stationary at $\mathrm{I}(1)$ so that we can continue to determine the optimal lag length.

Table 2. Result of unit root test at I(0)

\begin{tabular}{llllllll}
\hline \multirow{2}{*}{ Variable } & \multirow{2}{*}{ Lag } & \multirow{2}{*}{ t-Statistic } & \multicolumn{3}{c}{ Test Critical Values } & \multirow{2}{*}{ Probability } & \multirow{2}{*}{ Result } \\
\cline { 4 - 6 } & & & $1 \%$ & $5 \%$ & $10 \%$ & & \\
\hline PSS & 0 & -0.949658 & -3.525618 & -2.902953 & -2.588902 & 0.7666 & Not stationer \\
PL & 0 & -1.259373 & -3.525618 & -2.902953 & -2.588902 & 0.6440 & Not stationer \\
PJ & 0 & -1.105261 & -3.525618 & -2.902953 & -2.588902 & 0.7096 & Not stationer \\
PB & 0 & -0.984565 & -3.525618 & -2.902953 & -2.588902 & 0.7546 & Not stationer \\
PBB & 0 & -1.034813 & -3.525618 & -2.902953 & -2.588902 & 0.7365 & Not stationer \\
QSS & 1 & -0.908424 & -3.544063 & -0.910860 & -2.593090 & 0.7790 & Not stationer \\
QL & 1 & -1.015170 & -3.544063 & -0.910860 & -2.593090 & 0.7425 & Not stationer \\
QJ & 1 & -1.280578 & -3.544063 & -0.910860 & -2.593090 & 0.6331 & Not stationer \\
QB & 0 & -6.012523 & -3.527045 & -2.903566 & -2.589227 & 0.0000 & Stationer \\
QBB & 1 & -0.200263 & -3.525618 & -2.902953 & -2.588902 & 0.0000 & Stationer \\
\hline
\end{tabular}

\section{Optimal lag test}

Based on all criteria: LR (Likelihood Ration), FPE (Final Prediction Error), AIC (Akaike Information Criterion), SC (Schwarrz Information Criterion) and HQ (Hannan-Quinn Criterion), optimal lag is the first lag (value indicated with an asterisk). Based on Table 4, it can be concluded that the first lag is the optimal lag for rice model in Southern Sumatra. It implies that all existing variables in the model affect each other not only in current period, but also inter-related in previous period. 
Table 3. Result of unit root test at I(1)

\begin{tabular}{llllllll}
\hline \multirow{2}{*}{ Variable } & \multirow{2}{*}{ Lag } & \multirow{2}{*}{ t-Statistic } & \multicolumn{2}{l}{ Test Critical Values } & \multirow{2}{*}{ Probability } & Result \\
\cline { 5 - 6 } & & & $1 \%$ & $5 \%$ & $10 \%$ & & \\
\hline PSS & 0 & -7.772146 & -3.527045 & -2.903566 & -2.589227 & 0.0000 & Stationer \\
PL & 0 & -8.633687 & -3.527045 & -2.903566 & -2.589227 & 0.0000 & Stationer \\
PJ & 0 & -9.034193 & -3.527045 & -2.903566 & -2.589227 & 0.0000 & Stationer \\
PB & 0 & -7.680166 & -3.527045 & -2.903566 & -2.589227 & 0.0000 & Stationer \\
PBB & 0 & -6.597559 & -3.527045 & -2.903566 & -2.589227 & 0.0000 & Stationer \\
QSS & 0 & -7.300878 & -3.544063 & -2.910860 & -2.583090 & 0.0000 & Stationer \\
QL & 0 & -9.198687 & -3.544063 & -2.910860 & -2.583090 & 0.0000 & Stationer \\
QJ & 0 & -10.30639 & -3.544063 & -2.910860 & -2.583090 & 0.0000 & Stationer \\
QB & 0 & -7.191385 & -3.527045 & -2.903566 & -2.589227 & 0.0000 & Stationer \\
QBB & 0 & -0.200263 & -3.525618 & -2.902953 & -2.588902 & 0.0000 & Stationer \\
\hline
\end{tabular}

Table 4. Result of lag optimal test based on LR, FPE, AIC, SC, and HQ

\begin{tabular}{clllll}
\hline Lag & LR & FPE & AIC & SC & HQ \\
\hline 0 & NA & $1.14 \mathrm{e}+24$ & 69.58273 & 70.57803 & 69.97602 \\
1 & $309.8305^{*}$ & $8.84 \mathrm{e}+21^{*}$ & $64.70702^{*}$ & $66.53174^{*}$ & $65.42806^{*}$ \\
2 & 19.70280 & $1.31 \mathrm{e}+22$ & 65.07054 & 67.72467 & 66.11932 \\
3 & 13.57558 & $2.21 \mathrm{e}+22$ & 65.52644 & 69.00998 & 66.90295 \\
4 & 28.94660 & $2.56 \mathrm{e}+22$ & 65.56035 & 69.87331 & 67.26461 \\
5 & 36.07649 & $2.32 \mathrm{e}+22$ & 65.28717 & 70.42954 & 67.31917 \\
6 & 19.46725 & $3.37 \mathrm{e}+22$ & 65.39584 & 71.36762 & 67.75557 \\
\hline
\end{tabular}

*Indicates lag order selected by the criterion

\section{VAR stability test}

Stability of VAR system can be seen from the inverse roots value of its polinominial autoregression characteristics. System of VAR is stable (stationer) when all its roots have modulus than all of them are located inside the circle unit.

Table 5. Result of stability test in VAR model

\begin{tabular}{ll}
\hline Root & Modulus \\
\hline 0.992733 & 0.992733 \\
0.811082 & 0.811082 \\
$0.340604-0.498326 \mathrm{i}$ & 0.603605 \\
$0.340604+0.498326 \mathrm{i}$ & 0.603605 \\
$0.444557-0.119326 \mathrm{i}$ & 0.460293 \\
$0.444557+0.119326 \mathrm{i}$ & 0.460293 \\
-0.423025 & 0.423025 \\
$-0.080419-0.290713 \mathrm{i}$ & 0.301631 \\
$-0.080419+0.290713 \mathrm{i}$ & 0.301631 \\
0.101338 & 0.101338 \\
\hline
\end{tabular}

If data is not stable, then data is not robust for VAR model (Lutkepohl, 2004). Table 5 presents VAR test and show that all data in this study is stable at its optimal lag.

No root lies outside the unit circle.

VAR satisfies the stability condition.

\section{Cointegration test}

Table 6 shows the results of cointegration test. Based on trace-test and Max-eigenvalue test indicates that there is cointegration in rank $=0$ (at most none). Trace test value are greater than critical value by 10 percent on rice model. There

Table 6. Result of cointegration analysis in rice model

\begin{tabular}{llccccc}
\hline \multirow{2}{*}{ Hypothesized } & \multicolumn{3}{c}{ Trace } & \multicolumn{3}{c}{ Max-Eigenvalue } \\
\cline { 2 - 6 } & Trace-stat & CV =10 \% & Prob**. & Max-Eigen stat & CV =10 \% & Prob** \\
\hline None* & 67.32110 & 65.81970 & 0.0778 & 32.60034 & 3123922 & 0.0704 \\
At most 1 & 34.72076 & 44.49359 & 0.4628 & 16.77035 & 25.12408 & 0.5997 \\
At most 2 & 17.95041 & 27.06695 & 0.5697 & 12.12196 & 18.89282 & 0.5357 \\
At most 3 & 5.828454 & 13.42878 & 0.7157 & 5.823543 & 12.29652 & 0.6360 \\
At most 4 & 0.004910 & 2.705545 & 0.9432 & 0.004910 & 2.705545 & 0.9432 \\
\hline
\end{tabular}

Trace test indicates 1 cointegration at the 0.10 level

Max-eigenvalue test indicate 1 cointegration at the 0.10 level

$*$ denotes rejection of the hypothesis at the 0.10 level

**MacKinnon et al. (1983) p-values and rank 4 (at most 4). It means that in the long run this model has only one linear equation. is no cointegration between rank $=1$ (at most 1 ) 
Because there is only one co-integrating vector (Vector Autoregression) or stationary linear combination in rice market, then the analysis of long-term co-integration vectors can be specified for rice price in producers/exporters province. This is because of the rice produced by surplus province is mostly exported, so that domestic rice prices in surplus provinces affected by consumer/ importer province.

\section{Vector error correction model (VECM)}

VECM is a combination of short run and long rung relationship to the different markets prices (Anwar, 2006). Coefficients of ECT in VECM model is a measure of speed adjustment towards long run equilibrium relationship between market (Enders, 1995). Table 7 presents longterm cointegration equation of rice price. It stated that there is long run equilibrium relationship between rice market in South Sumatra province with rice market in Lampung province, Jambi province, Bengkulu province, and Bangka Belitung province. If these results are associated with the results of long-term cointegration vectors that are specified for rice price in South Sumatra province, then it can be said that in the long run, rice price in Jambi province and Bangka Belitung province will be reference rice price in South Sumatra province.

Table 7. Rice price cointegration equation in the long term

\begin{tabular}{lccccc}
\hline Cointegration & \multicolumn{5}{c}{ Rice price variable } \\
\cline { 2 - 5 } equation & PSS & PL & PJ & PB & PBB \\
\hline (CE) & 1.000000 & 0.728804 & 2.253475 & 0.691296 & -0.187683 \\
(CE) 1 & & {$[140155]^{\text {b) }}$} & {$[5.02407]^{\mathrm{a})}$} & {$[1.78329]^{\mathrm{b})}$} & {$[-1.98410]^{\mathrm{b})}$} \\
\hline
\end{tabular}

Note: a) significant in $5 \%$ level of confidence; b) significant in 20\% level of confidence

Tabel 8. VECM coefficient value in Southern Sumatra market integration equation

\begin{tabular}{|c|c|c|c|c|c|}
\hline \multirow{2}{*}{$\begin{array}{l}\text { Error } \\
\text { correction: }\end{array}$} & \multicolumn{5}{|c|}{ Endogen variable } \\
\hline & $\overline{\mathrm{D} \text { (PSS) }}$ & $\overline{\mathrm{D}(\mathrm{PJ})}$ & D(PL) & $\mathrm{D}(\mathrm{PB})$ & $\overline{D(P B B)}$ \\
\hline \multirow{3}{*}{ CointEq1 } & -0.084338 & 0.172047 & -0.102017 & -0.191725 & 0.232089 \\
\hline & $(0.09464)$ & (0.10928) & $(0.12680)$ & $(0.11171)$ & $(0.09051)$ \\
\hline & [-0.89111] & [1.57441] & {$[-0.80454]$} & [-1.71626] & [2.56436] \\
\hline \multirow[t]{3}{*}{ D(PSS(-1) } & -0.011687 & 0.090113 & 0.080541 & 0.444812 & 0.164694 \\
\hline & $(0.23823)$ & $(0.27506)$ & $(0.31918)$ & $(0.28119)$ & $(0.22781)$ \\
\hline & {$[-0.04906]$} & [0.32761] & [0.25234] & [1.58189]c) & [0.72294] \\
\hline \multirow[t]{3}{*}{$\mathrm{D}(\mathrm{PJ}(-1)$} & 0.232925 & -0.181689 & -0.029570 & -0.335704 & 0.275624 \\
\hline & $(0.18829)$ & $(0.21740)$ & (0.25226) & $(0.22224)$ & (0.18005) \\
\hline & $\left.[1.23708]^{e}\right)$ & {$[-0.83574]$} & {$[-0.11722]$} & {$[-1.51054]^{\mathrm{c})}$} & {$[153080]^{\mathrm{c})}$} \\
\hline \multirow[t]{3}{*}{$\mathrm{D}(\mathrm{PL}(-1)$} & 0.040908 & 0.023872 & -0.241871 & -0.111717 & 0.037464 \\
\hline & (0.19645) & (0.22682) & (0.26320) & (0.23187) & (0.18786) \\
\hline & [0.20824] & [ 0.10525] & [-0.91897] & {$[-0.48180]$} & [ 0.19943] \\
\hline \multirow[t]{3}{*}{$\mathrm{D}(\mathrm{PB}(-1)$} & 0.232738 & -0.106597 & 0.333242 & 0.095361 & 0.135285 \\
\hline & (0.19975) & $(0.23063)$ & $(0.26762)$ & $(0.23577)$ & $(0.19101)$ \\
\hline & {$[1.16516]^{\mathrm{e}}$} & {$[-0.46219]$} & {$[1.24520]^{\mathrm{e})}$} & {$[0.40447]$} & {$[0.70824]$} \\
\hline \multirow[t]{3}{*}{$\mathrm{D}(\mathrm{PBB}(-1)$} & 0.144418 & 0.153894 & -0.281918 & -0.103924 & -0.221513 \\
\hline & $(0.16312)$ & (0.18834) & $(0.21854)$ & (0.19253) & (0.15598) \\
\hline & [0.88536] & [0.81712] & $\left.[-1.29000]^{d}\right)$ & {$[-0.53977]$} & $\left.[-1.42010]^{d}\right)$ \\
\hline \multirow[t]{3}{*}{$\mathrm{C}$} & 135.0245 & 215.2045 & 120.8750 & 121.1336 & 185.8815 \\
\hline & (90.0766) & (104.004) & (120.683) & (106.321) & (86.1379) \\
\hline & [1.49900] & [2.06920] & [1.00159] & [1.13932] & [2.15795] \\
\hline \multirow[t]{3}{*}{ QSS } & $5.38 \mathrm{E}-07$ & $-8.90 \mathrm{E}-07$ & $1.45 \mathrm{E}-08$ & $-7.83 E-08$ & $1.18 \mathrm{E}-07$ \\
\hline & (5.5E-07) & (6.4E-07) & (7.4E-07) & (6.5E-07) & (5.3E-07) \\
\hline & [0.97777] & $\left.[-1.39958]^{d}\right)$ & [0.01966] & {$[-0.12042]$} & [0.22417] \\
\hline \multirow[t]{3}{*}{ QJ } & $-7.11 E-07$ & $1.33 \mathrm{E}-06$ & $1.53 \mathrm{E}-06$ & 2.23E-06 & 1.65E-06 \\
\hline & (3.3E-06) & (3.8E-06) & $(4.4 \mathrm{E}-06)$ & (3.8E-06) & (3.1E-06) \\
\hline & {$[-0.21853]$} & [0.35328] & [0.35083] & [0.58195] & [0.52996] \\
\hline \multirow[t]{3}{*}{ QL } & $-1.55 \mathrm{E}-07$ & $-1.89 E-07$ & $-9.76 E-07$ & $-8.44 \mathrm{E}-07$ & $-7.27 \mathrm{E}-07$ \\
\hline & (5.4E-07) & (6.3E-07) & (7.3E-07) & (6.4E-07) & (5.2E-07) \\
\hline & {$[-0.28570]$} & {$[-0.30104]$} & {$[-134046]^{d)}$} & {$[-1.31543]^{\mathrm{d})}$} & {$[-1.39893]^{\mathrm{d})}$} \\
\hline \multirow[t]{3}{*}{ QB } & $-1.24 \mathrm{E}-06$ & $-4.47 \mathrm{E}-06$ & $-4.28 \mathrm{E}-06$ & $-5.44 \mathrm{E}-06$ & -8.89E-06 \\
\hline & (3.6E-06) & $(4.2 \mathrm{E}-06)$ & $(4.9 \mathrm{E}-06)$ & $(4.3 \mathrm{E}-06)$ & (3.5E-06) \\
\hline & {$[-0.34025]$} & [-1.06319] & {$[-0.87684]$} & $\left.[-1.26684]^{e}\right)$ & {$[-2.55270]^{\mathrm{a})}$} \\
\hline \multirow[t]{3}{*}{ QBB } & $5.26 \mathrm{E}-05$ & $3.22 \mathrm{E}-05$ & $9.00 \mathrm{E}-05$ & 9.53E-05 & $6.74 \mathrm{E}-05$ \\
\hline & $(2.4 \mathrm{E}-05)$ & (2.7E-05) & (3.2E-05) & $(2.8 \mathrm{E}-05)$ & (2.3E-05) \\
\hline & [2.20839]а) & [1.17284]e) & [2.82077]a) & [3.39140] a) & {$[2.96328]^{a)}$} \\
\hline R-squared & 0.304297 & 0.287403 & 0.351196 & 0.422312 & 0.423494 \\
\hline F-statistic & 2.306262 & 2.126589 & 2.854120 & 3.854569 & 3.873283 \\
\hline
\end{tabular}

Note: $\quad$ ECT $=$ Error Correction Term; D = Operator in first differentiation; [ ] t-count

a)significant in $5 \%$ level of confidence; b) significant in $10 \%$ level of confidence; c)significant in $15 \%$ level of confidence; d)significant in $20 \%$ level of confidence; e) significant in $25 \%$ level of confidence; f) significant in $30 \%$ level of confidence 
Table 8 shows the VECM coefficients. The coefficients of Error Correction Term (ECT) illustrate speed adjustment towards equilibrium LR per period. In the rice market of Southern Sumatra, each province has ECT coefficient as follow: South Sumatra province (-0.084338), Lampung province (0.102017), Jambi province (0.172047), Bengkulu Province (-0.191725) and Bangka Belitung province (0.2032089).

Although the effect is small because its value less than one, but the coefficient of Jambi province has significant influence at 5 percent level of confidence to price rice change.

Bengkulu province and Bangka Belitung has influence price of rice at 10 percent level of confidence. Lampung province has influence price of rice at 20 percent level of confidence. It is indicated the important of LR cointegration relationship in process of determining rice price in rice market.

Rice price change in column $\mathrm{D}$ (PSS), $\mathrm{D}(\mathrm{PL})$, $\mathrm{D}(\mathrm{PJ}), \mathrm{D}(\mathrm{PB}), \mathrm{D}(\mathrm{UN})$ with the line (D (PSS (-1) and so on describe the magnitude of adjustments due to short-term change of price changes in the previous times toward change of current price (dependent variable).

Prices changes in South Sumatra will be influenced by rice price of Jambi province and Bengkulu province at first lag. It means that rice market in South Sumatra province is affected by earlier change of rice price in J ambi province and Bengkulu province. Rice price change in South Sumatra also affected by rice production in Bangka Belitung province. When rice price in South Sumatra province is down, then rice producers in Bangka Belitung province will not export rice to South Sumatra province.

Rice prices in Jambi province is affected by rice production in South Sumatra province. When rice production in South Sumatra province is abundant and rice price tend to go down, then rice producers will export their rice to other province which have higher price. Jambi province is one of rice importer from South Sumatra province.

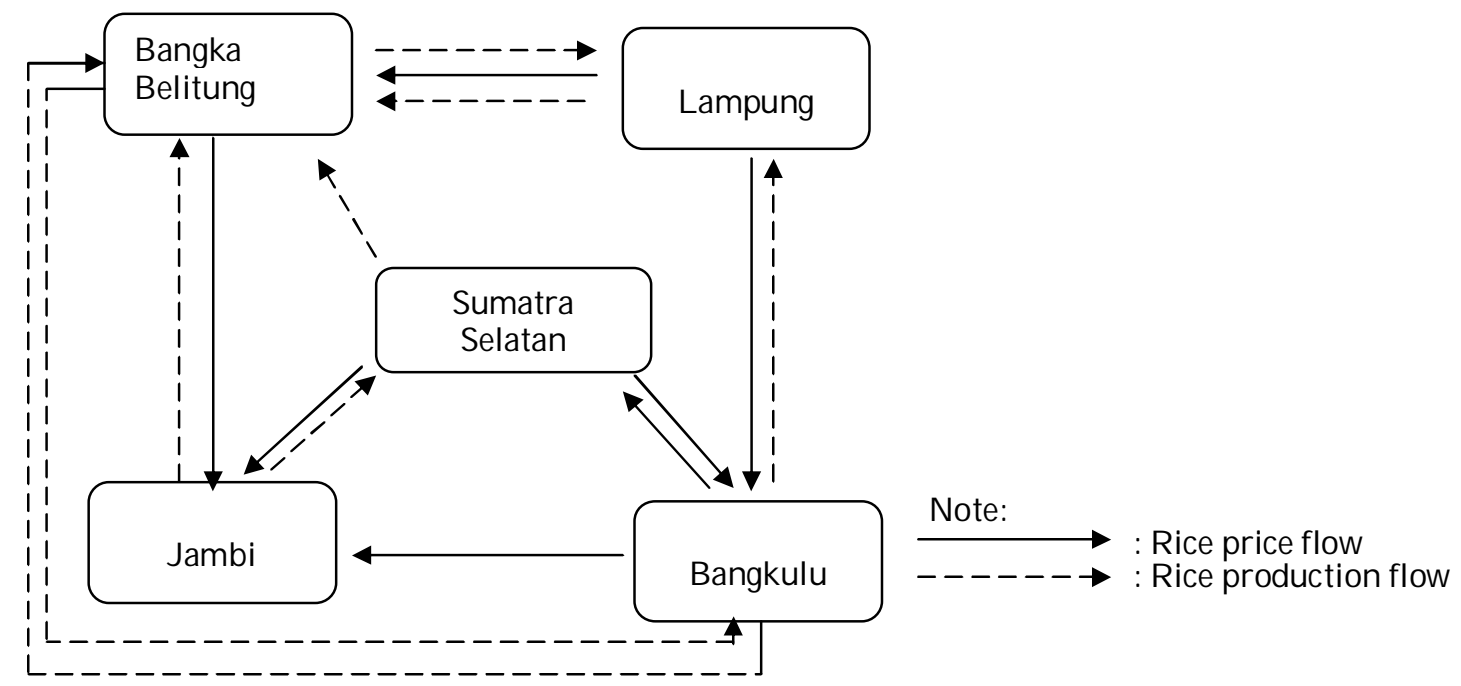

Fig. 1. Rice market integration in Southern Sumatra
Price changes in Jambi province also influenced by rice production in South Sumatra province and Bangka Belitung province. When rice production in this province is positive, rice prices tend to fall, and Jambi province has little rice production, then rice producer in South Sumatra prefer export their rice to Jambi province than Bangka Belitung province.

Rice price in Lampung province influenced by rice price in Bengkulu province and Bangka Belitung province. Bengkulu province and Bangka Belitung province is also import their rice from Lampung province. When rice price in Bengkulu province and Bangka Belitung province is high, then rice producer in Lampung will export their rice to these provinces. While rice price in Lampung province is also affected by rice production in their area and Bangka Belitung province.

Bengkulu and Bangka Belitung province import rice from Lampung province. When rice price in Bengkulu and Bangka Belitung is high, then rice producer in Lampung province tend to export rice to Bengkulu and Bangka Belitung province. Rice price change in Lampung province also influences by rice production in its area and Bangka Belitung province.

Rice price change in Bengkulu province is influenced by rice price in South Sumatra province and Jambi province. When rice price in J ambi province is down, rice price in Bengkulu is will prefer go to Bengkulu province than Jambi province. Rice price in Bengkulu province is influenced by rice production in their area, Lampung province, and Bangka Belitung province.

Rice price change in Bangka Belitung province is influenced by rice price change in J ambi province and in their area. It is also affected by rice production in their area, Lampung province, and Bengkulu province. From description on the above, the flow of rice market integration in Southern Sumatra region can be drawn in Fig. 1. positive, then rice from South Sumatra province 
Table 9. Rice price change in Southern Sumatra

\begin{tabular}{llll}
\hline No. & Endogen variable & CointEq1 & Time moving (month) \\
\hline 1. & D(PSS) & -0.084338 & 11.85 \\
2. & D(PJ) & 0.172047 & 5.81 \\
3. & D(PL) & -0.102017 & 9.80 \\
4. & D(PB) & -0.191725 & 5.21 \\
5. & D(PBB) & 0.232089 & 4.30 \\
\hline
\end{tabular}

Table 9 presents a negative value of rice price in South Sumatra province, Lampung province and Bengkulu province. This negative value means that the significant value of rice at the beginning period is higher than in the current period, and vice versa. Positive significant value of rice in Jambi Province and Bangka Belitung province showed that the significant value of rice price in the early period is lower than the current period. These data indicate that in the short term if the significant prices stayed in above the equilibrium point, then government failed to lower rice price which may be due to a lack of rice supply. Table 9 stated that Bangka Belitung province will more quickly make adjustments in price compared to other provinces.

\section{Conclusion}

It can be concluded that there has been spatial market integration in Southern Sumatra. Specifically, it can be said that: (a) South Sumatra rice market is affected by rice market in Bengkulu and Lampung provinces; (b) J ambi rice market is affected by rice market in South Sumatra province, Bangka Belitung province and Lampung Province; (c) Lampung rice market is affected by its own market and Bengkulu rice market;; (d) Bengkulu rice market is affected by its own market, South Sumatra and Lampung rice market; and (e) Bangka Belitung rice market is affected by rice market in J ambi and Bengkulu province.

To keep stability of rice price in Southern Sumatra, it is suggested for government to improving information management on rice price and simplication of marketing and distribution chain. Government intervention in rice price still needed as a guidance for others actor in rice trading. Government must keep their attention to agricultural sector as whole. Because Indonesia will entering ASEAN Economic Community (AEC) in 2015, then it is important to investigate in the next research how ASEAN Economic Community (AEC) influenced rice price.

\section{Acknowledgement}

This article is a part of my dissertation in Department of Agriculture, University of Sriwijaya, Palembang, Indonesia. It has been presented in national seminar on "Penguatan Agribisnis Perberasan Guna Mewujudkan Kemandirian dan Kesejahteraan Petani", organized by Magister Manajemen Agribisnis University of Gadjah Mada and PERHEPI (Perhimpunan Ekonomi Pertanian Indonesia), in Yogyakarta, 7-8 May 2012. We are giving to thanks for all people who give positive contribution until finalisation of this project.

\section{References}

Alexander, C. and Wyeth, J. 1994. Cointegration and market integration: an application to the Indonesian rice market. J. Dev. Stud. 30(2): 303-328.

Anwar, C. 2006. Perkembangan Pasar dan Prospek Agribisnis Karet di Indonesia. Prosiding Lokakarya Nasional Budidaya Tanaman Karet, Medan, 4-6 September 2006. pp. 1-19.

Bustaman, A.D. 2003. Integrasi Pasar Beras di Indonesia. Bogor, Indonesia: Bogor Agricultural Institute. pp. 122-128. Retrieved from http:// repository.ipb.ac.id/ handle/ 1234567 89/14894

Central Bureau of Statistic. 2012. Produksi Tanaman Pangan, J akarta, Indonesia: Central Bureau of Statistics. Retrieved from http:// bps.go.id/linkTableDinamis/ view/id / 866, accessing date: 2 September 2012.

Enders, W. 1995. Applied econometric time series, New Jersey: John Wiley and Sons. pp. 355-385.

Lutkepohl, H. 2004. Univariate time series analysis. In: Lutkepohl, $\mathrm{H}$. and Kratzig, M. (eds.). Applied Time Series Econometrics. Cambridge, United Kingdom: Cambridge University Press. pp. 8-85.

MacKinnon, J., White, H. and David, R. 1983. Test for model specification in the presence of alternative hypothesis: some further result. J. Econometr. 21: 53- 70.

Maknun, M.J. 2008. Integrasi pasar uang negara ASEAN dan Hongkong. Yogyakarta, Indonesia: Universitas Islam Indonesia. pp. 1-250. Retrieved from http:// rac.uii.ac.id/ server/ document/Privat e/2008042404083004313067.pdf

Pindyck, R. and Rubinfeld, D.L. 1981. Econometric model and economics forecasts, Boston, USA: Irwin McGraw-Hill. pp. 514-515

Ravallion, M. 1986. Testing Market Integration. American J. Agril. Econ. 68(1): 102- 109.

Thomas, R.L. 1997. Modern econometrics: an introduction, Edinburg: Addison-Wesley Longman Limited. pp. 427-450.

Trotter, B. 1992. Applying price analysis to marketing system: methods and example from the Indonesia rice markets. Marketing Series Volume 4. Ghatam, United Kingdom: Natural Research Institute. pp. 1-40.

Varela, G., Aldaz-carroll, E. and Iacovone, L. 2013. Determinants of market integration and price transmission in Indonesia. J. Southeast Asian Stud. 30(1): 19-44.

Widarjono, A. 2007. Ekonometrika: teori dan aplikasi untuk ekonomi dan bisnis, Yogyakarta: Penerbit Ekonisia. pp. 372-390. 